\title{
Problems and Countermeasures for Course Teaching of "Contemporary Chinese Language" in Normal Colleges
}

\author{
Linbo Hou \\ Xiangnan Preschool Education College \\ Chenzhou, Hunan, China
}

\author{
Jisheng $\mathrm{He}^{*}$ \\ XiangNan University \\ Chenzhou, Hunan, China \\ *Corresponding author
}

\begin{abstract}
Normal colleges aim to cultivate some general teachers, which weakens the teaching of "Contemporary Chinese Language". As a result, students are lack of learning incentive, so the teaching effect is unsatisfactory. Aiming at existing problems, the author explores new methods and forms following referential strategies: adjusting teaching goals, catering to professional needs; enriching teaching tools, corresponding with characteristics of the times; optimizing teaching methods, enhancing students' interest; selecting teaching contents, highlighting the key contents of courses; improving evaluation models, motivating the learning vitality.
\end{abstract}

Keywords-contemporary Chinese language; teaching; problems; countermeasures

\section{INTRODUCTION}

Contemporary Chinese language is an important basic subject and required course of normal school students, whose teaching objective is to help students master the basic knowledge and basic skills in a comprehensive and systematic way. Therefore, it can train students' basic skills of analyzing the pronunciation, characters, vocabulary, grammar, and figure of speech of contemporary Chinese language. [1] It tells the theoretical knowledge, analyzing methods, as well as the standard of language for contemporary Chinese language, so it is an important guarantee for students to master basic theories and knowledge of contemporary Chinese language in a systematic way, and enhance their ability of analyzing and comprehending contemporary Chinese language. Meanwhile, it helps them cultivate professional qualities of being a teaching. However, viewing from the current status of normal colleges, the situation is worrying. For example, teaching content is boring; teaching method is lagging behind; students are lack of interest; and teaching effect is poor. Therefore, it urgently needs to seek good medicine to break the bottleneck.

The author has conducted a survey in schools, and interviewed 21 students and 2 teachers, to adopt their opinions about the teaching of "Contemporary Chinese Language". During the period of questionnaire survey, the author gave out 345 questionnaires and collected 326, with the recovery rate of

Teaching reform and research project of regular institutes of higher education in Hunan Province in 2016. The project is named as Research and Practice on Cultivation Strategy of Application-oriented Teachers in Primary and Secondary Schools. ( XiangJiaoTong[2016]No.400-738), scientific research project in Xiangnan University in 2016 "the application technology of Changzhou education development countermeasure research (2016xj26)
94.5\%. The questionnaire is designed from schools, courses, teaching, and students, with totally 25 questions.

\section{EXISTING PROBLEMS}

\section{A. School's attention should be strengthened}

The interview tells that: contemporary Chinese language opens for one year, with 2 periods each week and totally 64 periods. In order to finish the teaching tasks of pronunciation, characters, vocabulary, grammar, figure of speech, and pragmatics in such a few periods, teachers have to catch up with progress, and even end up some contents when it only begins to learn. First, students think that the teaching period is seriously deficient, and $92.3 \%$ students think that it lacks teaching hours. Second, teaching materials are randomly selected, and some contents in the teaching materials do not meet students' actual needs in the future. Third, there are few activities, such as "speech contest" and "writing contest of Chinese characters". Fourth, evaluation method for this course is single, which only relies on test for theoretical knowledge, but without the test for practical ability. For this, only $19.3 \%$ agree with this evaluation method, while $48.8 \%$ students do not agree with it. The above points illustrate that colleges have not pay enough attention to this course, and do not treat it as a core major course. (see TABLE I)

TABLE I. ABOUT COLLEGES

\begin{tabular}{|c|c|c|c|}
\hline Questions & \multicolumn{3}{|c|}{ Options and results } \\
\hline $\begin{array}{c}\text { How do you think the } \\
\text { teaching arrangement of } \\
\text { the course? }\end{array}$ & $\begin{array}{c}\text { Not enough } \\
(231, \\
70.9 \%)\end{array}$ & $\begin{array}{c}\text { Very tight } \\
(70,21.5 \%)\end{array}$ & $\begin{array}{c}\text { Enough } \\
(25,7.67 \%)\end{array}$ \\
\hline $\begin{array}{c}\text { Does the college pay } \\
\text { much attention to this } \\
\text { course? }\end{array}$ & $\begin{array}{c}\text { Very much } \\
(105, \\
32.2 \%)\end{array}$ & $\begin{array}{c}\text { So-so } \\
(204,62.6 \%)\end{array}$ & $\begin{array}{c}\text { Not much } \\
(23,7.06 \%)\end{array}$ \\
\hline $\begin{array}{c}\text { Does the college have } \\
\text { practical activities about } \\
\text { this course? }\end{array}$ & $\begin{array}{c}\text { Many } \\
(122,\end{array}$ & $\begin{array}{c}\text { Not many } \\
(117,35.9 \%)\end{array}$ & $\begin{array}{c}\text { Few } \\
(87,26.7 \%)\end{array}$ \\
\hline $\begin{array}{c}\text { How do you think the } \\
\text { teaching materials of this } \\
\text { course? }\end{array}$ & $\begin{array}{c}\text { Very good } \\
(78,23.9 \%)\end{array}$ & $\begin{array}{c}\text { Common } \\
(157,48.2 \%)\end{array}$ & $\begin{array}{c}\text { Bad } \\
(91,27.9 \%)\end{array}$ \\
\hline $\begin{array}{c}\text { How do you think the } \\
\text { evaluation method of } \\
\text { this course? }\end{array}$ & $\begin{array}{c}\text { Reasonable } \\
(63,19.3 \%)\end{array}$ & $\begin{array}{c}\text { Basically } \\
\text { reasonable } \\
(104,31.9 \%)\end{array}$ & $\begin{array}{c}\text { Unreasonable } \\
(159,48.8 \%)\end{array}$ \\
\hline \multicolumn{2}{|c}{} \\
\hline
\end{tabular}




\section{B. The course understanding level needs to be improved}

$26.7 \%$ students do not understand the teaching objectives of the course, and do not know much about the course requirements. Subjectively speaking, they think the status of "contemporary Chinese language" is low, and it is not interesting, so its ability of helping students improve their Chinese language qualities and professional ability is limited. $12.9 \%$ students think it does not relate to students' Chinese level. This course is theoretical, which focuses on practical application, so students may feel difficult when they learn it.
However, only 5.83\% students think it is not difficult. Viewing from its relation with real life, most students feel that it does not have much relation with life, and it does not reflect the teaching theory in life. While only $17.8 \%$ students think that this course greatly links with life, but it does not have intense connection with other major courses, so it is difficult to connect them. It is hard to master the inner connection of chapters within the course, so students may feel free among the modules of the learning contents. Gradually, they will lose the interest of learning, and $41.1 \%$ students do not have any interest in it. (see TABLE II)

TABLE II. ABOUT THE COURSE

\begin{tabular}{|c|c|c|c|}
\hline Questions & \multicolumn{3}{|c|}{ Options and results } \\
\hline Do you understand the objectives of this course? & Understand a lot $(65,19.9 \%)$ & Understand some $(174,53.4 \%)$ & Not understand(87, 26.7\%) \\
\hline $\begin{array}{l}\text { Do you think learning th is course can help improve students' } \\
\text { Chinese language level? }\end{array}$ & Very useful(91, 27.9\%) & Useful(193, 59.2\%) & Not useful(42, 12.9\%) \\
\hline Do you think it is interesting to learn this course? & Very interesting(58, 17.8\%) & Interesting $(187,57.4 \%)$ & Not interesting $(81,24.8 \%)$ \\
\hline How is the status of this course in major courses? & Very high(32, 9.82\%) & High $(108,33.1 \%)$ & Not high(186, 57.1\%) \\
\hline Do you think the knowledge module of the course is clear? & Very clear(234, $71.8 \%)$ & Clear(67, 20.6\%) & Not clear(25, $7.67 \%)$ \\
\hline $\begin{array}{l}\text { Does the content connect with the knowledge in middle } \\
\text { school? }\end{array}$ & Connected well(105, 32.2\%) & $\begin{array}{c}\text { Basically connected(224, } \\
68.7 \%)\end{array}$ & Not connected(3, 0.09\%) \\
\hline Does the course closely link with other major courses? & Closely linked(142, 43.6\%) & Linked(97, 29.8\%) & Not close(87, 26.7\%) \\
\hline Does the teaching content relate to life? & Greatly related(58, $17.8 \%)$ & Related(187, 19.2\%) & Hardly related(81, $19.2 \%)$ \\
\hline Is it difficult to learn this course? & Very difficult(99, 19.2\%) & Difficult(208, 57.4\%) & Not difficult(19, 5.83\%) \\
\hline Are you interested in learning this course? & Very interested(68, 20.9\%) & Interested(124, 38.0\%) & Not interested(134, 41.1\%) \\
\hline
\end{tabular}

\section{Teachers' teaching should be optimized}

Teachers' teaching concept is lagging behind, which lacks the ability of mobilizing students' subjective initiative, cannot well connect the theory with reality, does not face students' professional needs, and hardly connect with life. Traditional teaching methods are still in dominant position, and teachers are lack of new teaching theories, so teaching methods need to be optimized. Meanwhile, the application of teaching tools is lagging behind, and information teaching is slowly pushed ahead. When teachers arrange tasks, they only pay attention to the practice of basic knowledge, but not practical application. $16.0 \%-30.4 \%$ students are not satisfied with the teaching. What's more, teachers do not adopt modern methods to enhance students' learning interest, and they seldom use videos or audios. Therefore, $18.7 \%$ students think it still has difficulty in mobilizing their activity. (see TBALE III)

TABLE III. ABOUT TEACHING

\begin{tabular}{|c|c|c|c|}
\hline Questions & \multicolumn{3}{|c|}{ Options and results } \\
\hline How about the application of information tools in classrooms? & Always(67, 20.6\%) & Occasionally(189, 58.0\%) & $\begin{array}{l}\text { Seldom(70, } \\
21.5 \%)\end{array}$ \\
\hline $\begin{array}{l}\text { How about the combination of teaching theory and practice in } \\
\text { classrooms? }\end{array}$ & Very well $(108,33.1 \%)$ & Common(174, 53.4\%) & $\operatorname{Poor}(44,13.5 \%)$ \\
\hline How about the mobilization of students' activity? & Very $\operatorname{good}(87,26.7 \%)$ & Always(178, 54.6\%) & $\begin{array}{c}\text { Seldom(61, } \\
18.7 \%)\end{array}$ \\
\hline When teachers arrange tasks, is the design reasonable and valuable? & $\begin{array}{l}\text { Very reasonable and valuable(88, } \\
27.0 \%)\end{array}$ & Sometimes(186, $57.1 \%)$ & No(52, $16.0 \%)$ \\
\hline Does classroom teaching face teachers' professional needs? & Very well(123, $37.7 \%)$ & Common (104, 31.9\%) & Bad (99, 30.4\%) \\
\hline
\end{tabular}

TABLE IV. ABOUT STUDENTS

\begin{tabular}{|c|c|c|c|}
\hline Questions & \multicolumn{3}{c|}{ Options and results } \\
\hline Have you heard about this course before entering college? & $\begin{array}{c}\text { Very familiar } \\
(34,10.4 \%)\end{array}$ & $\begin{array}{c}\text { Heard about it } \\
(47,14.4 \%)\end{array}$ & $\begin{array}{c}\text { Not know } \\
(245,75.2 \%)\end{array}$ \\
\hline After learning this course, have your Chinese been more solid? & $\begin{array}{c}\text { Very solid } \\
(49,15.0 \%)\end{array}$ & $\begin{array}{c}\text { Solid } \\
(265,81.3 \%)\end{array}$ & $\begin{array}{c}\text { Not meaningful } \\
(12,3.68 \%)\end{array}$ \\
\hline Has your language ability been improved? & $\begin{array}{c}\text { Improved a lot } \\
(169,51.8 \%)\end{array}$ & $\begin{array}{c}\text { Improved } \\
(114,35.0 \%)\end{array}$ & $\begin{array}{c}\text { Not improved } \\
(43,13.2 \%)\end{array}$ \\
\hline Have you sensed the charm of Chinese language? & $\begin{array}{c}\text { Strongly sensed } \\
(157,48.2 \%)\end{array}$ & $\begin{array}{c}\text { Sensed } \\
(161,49.4 \%)\end{array}$ & $\begin{array}{c}\text { Not sensed } \\
(8,0.25 \%)\end{array}$ \\
\hline Does your literary quality improved after learning this course? & $\begin{array}{c}\text { Improved a lot } \\
(89,27.3 \%)\end{array}$ & $\begin{array}{c}\text { Improved a little } \\
(204,62.6 \%)\end{array}$ & $\begin{array}{c}\text { Not improved } \\
(33,10.1 \%)\end{array}$ \\
\hline
\end{tabular}




\section{Students do not have good learning harvest.}

The survey finds out that students lack recognition for this course before they enter school, and only $10.4 \%$ students are clear about this course. Generally speaking, students think this course has powerful theory, so it is difficult for them to learn well. Through learning, we know that only $15.0 \%, 51.8 \%$, and $27.3 \%$ students feel they have good harvest in Chinese knowledge, language ability, and literary attainments. They can feel the charm of Chinese language, and their ability of using language has been enhanced. However, the feeling of other aspects is not obvious, and there is huge difference between the learning effect and expectation. (see TBALE IV)

\section{EFFeCtive Countermeasures}

\section{A. Adjust teaching objectives, and face professional needs}

The teaching aim of "Contemporary Chinese Language" is to cultivate students' ability of understanding, analyzing, and applying language. For students with different majors, the setting of teaching objectives should combine students' major orientation and employment trend. For example, in terms of normal college students, the teaching objective of this course should combine students' major orientation and employment trend of being a teacher. The selection of teaching contents should have some emphasis in accordance with the requirements and characteristics of teaching, and add practical application. Meanwhile, the teaching methods should be flexible and interesting, to create interactive atmosphere. Teaching evaluation should increase the proportion of applied test. [2] In specific, first, we must preset teaching objectives based on the special requirements of teachers' language. On the other hand, students must master the basic knowledge of Chinese language, cultivate good language qualities, and have good ability in listening and speaking. Second, we must train students' learning based on the requirements of teachers' organizing ability, and flexibly organize teaching. What's more, we must enhance the ability of applying theory to practice, and possess the ability of adjusting to changing circumstances.

\section{B. Enrich teaching tools, and cater to the characteristics of the times}

During the teaching process, we should guide students to know about the teaching requirements and teaching contents in accordance with students' characteristics of physical and mental development, as well as the features of the time. Generally speaking, students are avant-garde in thinking, because they are at the stage with active thinking and novelty. If teachers still adopt the primary teaching method with one book and one chalk, how can they arouse students' learning enthusiasm? With the development of the time and science, "internet" and "big data" are gradually becoming an indispensable part in people's life. However, as the constructor and successor of cultivating the cause of socialism, as well as imparting knowledge and educating people, how can teaching staff with the mission of enhancing a nation's quality lag behind in the information tide! Therefore, teachers must enrich their teaching tools, rely on multi-media technology and network technology, and apply visual effect and video effect, to enhance students' learning interest. At the same time, these teaching tools have many ways of communication, large information, and strong interaction, so it is good for optimizing classroom teaching. After class, teachers can also use QQ group and Wechat group to establish interactive platform for the communication between teachers and students, to help students realize external and internal cultivation.

\section{Optimize teaching methods, and enhance students' interest}

Teaching methods should not only consider about teachers' teaching, but also students' learning, because these two elements can complement each other. Meanwhile, the teaching of "Contemporary Chinese Language" can also be life-oriented, humanistic, and interesting. First, teachers should select suitable methods for students based on their physical and mental characteristics, as well as their knowledge level. Teachers should effectively guide students, act as directors, arouse students' self-consciousness and exploring spirit, and set up a bridge between Chinese language and actual application by making use of life-oriented teaching theory. In classroom teaching, teachers should combine revealing with correction, and focus on actual application. Pay attention to developing teaching resources, and skillfully organize activities like debate and competition. Create favorable classroom atmosphere, to enhance students' learning interest and participation enthusiasm. Second, teachers should guide students to learn, and cultivate their initiative in learning. If teachers teach some methods to help students solve problems, students can learn independently. In other words, teachers should train students' creative learning ability in teaching.

\section{Select teaching contents, and highlight the key contents of the course}

As Chinese language is extensive and profound, "Contemporary Chinese Language" contains widespread contents, including words, vocabulary, sentences, paragraphs, and passages, as well as sound, form, and meaning. However, it is rather difficult to collect all the contents within limited time. Therefore, teachers have to choose, and select some valuable contents, to connect with students' professional needs. Some teaching contents that have been taught in middle schools or do not have many benefits can be appropriately weakened. In other words, teachers should abide by the principle of optimizing teaching contents, to ensure the efficiency of teaching. For instance, dialect and grammatically wrong sentences should not occupy too much teaching time, while pragmatics and other contents with great link of profession should be explained concise and incisive. Meanwhile, teachers should regard digital course platform as extension and auxiliary of classes, to establish a platform for the exchange between teachers and students, and make up the shortcoming of classroom teaching. During the implementation process, teachers should pay special attention to practical activities, and present boring theories in the form of real living examples, to motivate the classroom energy and strengthen practical effect. 


\section{E. Improve evaluation model, and arouse the vitality of learning}

Traditional evaluation method usually evaluates by a piece of examination paper, which is not good for exerting students' self-consciousness and initiative spirit. As a result, it mitigates students' learning enthusiasm. "Contemporary Chinese Language" focuses on real application, and its course features decides that theories in education are meaningless if they are away from practice. Then, evaluation for students can not only rely on the score of examination paper, but also their application ability of language. Also, the design of examination papers should try to avoid pure objective questions, and add the proportion of subjective questions, to emphasize on students' language application. Besides, teachers should incorporate students' language activities and regular assignments into the evaluation system, to reflect scientific evaluation method. In this way, correct evaluation can be used as a baton to guide students' learning, and cultivate students' ability of analyzing and applying language.

\section{CONCLUSION}

There is no doubt that taking effective methods to improve the teaching of "Contemporary Chinese Language" driven by problems can solve currently embarrassing situation, and lead students to be active, but not passive. It can also help students be interested in learning, but not hate it, to improve the education quality.

\section{ACKNOWLEDGMENT}

The research has been sponsored by teaching reform and research project of regular institutes of higher education in Hunan Province in 2016. The project is named as Research and Practice on Cultivation Strategy of Application-oriented Teachers in Primary and Secondary Schools. (XiangJiaoTong[2016]No.400-738), scientific research project in Xiangnan university in 2016 'the application technology of chenzhou education development countermeasure research (2016xj26).

\section{REFERENCES}

[1] B.R. Huang, X.D. Liao. Contemporary Chinese Language, Beijing: Higher Education Press, 2008.

[2] Y.Y. Sun. "Current Status and Reflection on Contemporary Chinese Language Teaching for Major in Chinese Language \& Literature in Colleges,” Education and Teaching Research. pp. 91-98, Feb. 2016 .

[3] H.J. Ai, X. Li. "Cultivating Students' Innovation Ability in Contemporary Chinese Language Teaching,” China University Teaching Nov. 2011.

[4] B.K. Britton, A. Tesser. "Effect of time- management practices on College grades,” Journal of Educational Psycholog, Vol.83, pp. 405-410, Mar, 1991.

[5] X.T. Huang, Z.J. Zhang. “ Compilation of time management disposition scale for adolescents,” Acta Psychologica Sinica, Vol. 33, pp.338-343, Apr. 2001.

[6] [6] F. Zhang. "The research on the time management of self-controlling scale for middle school students,” psychological science, Vol. 30, pp. 668-671, Mar. 2007. 